



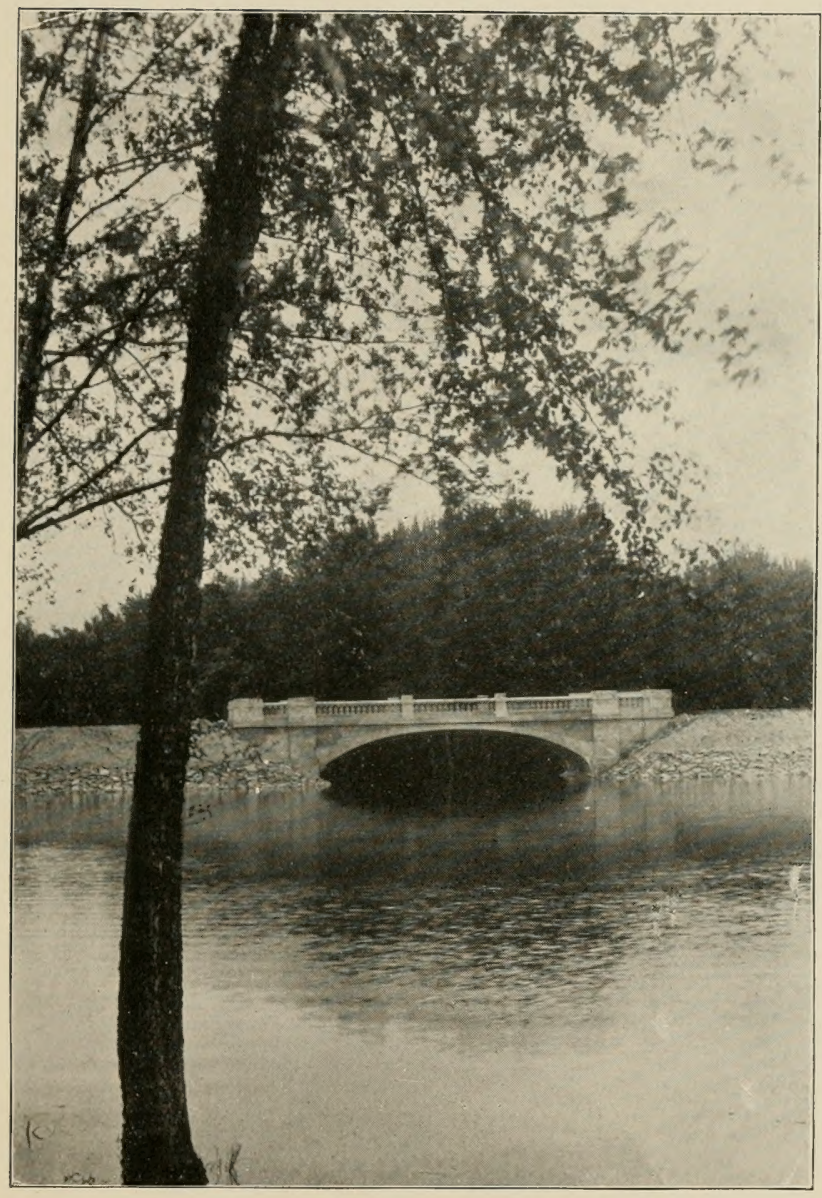

VIEW IN PETTIBONE PARK 


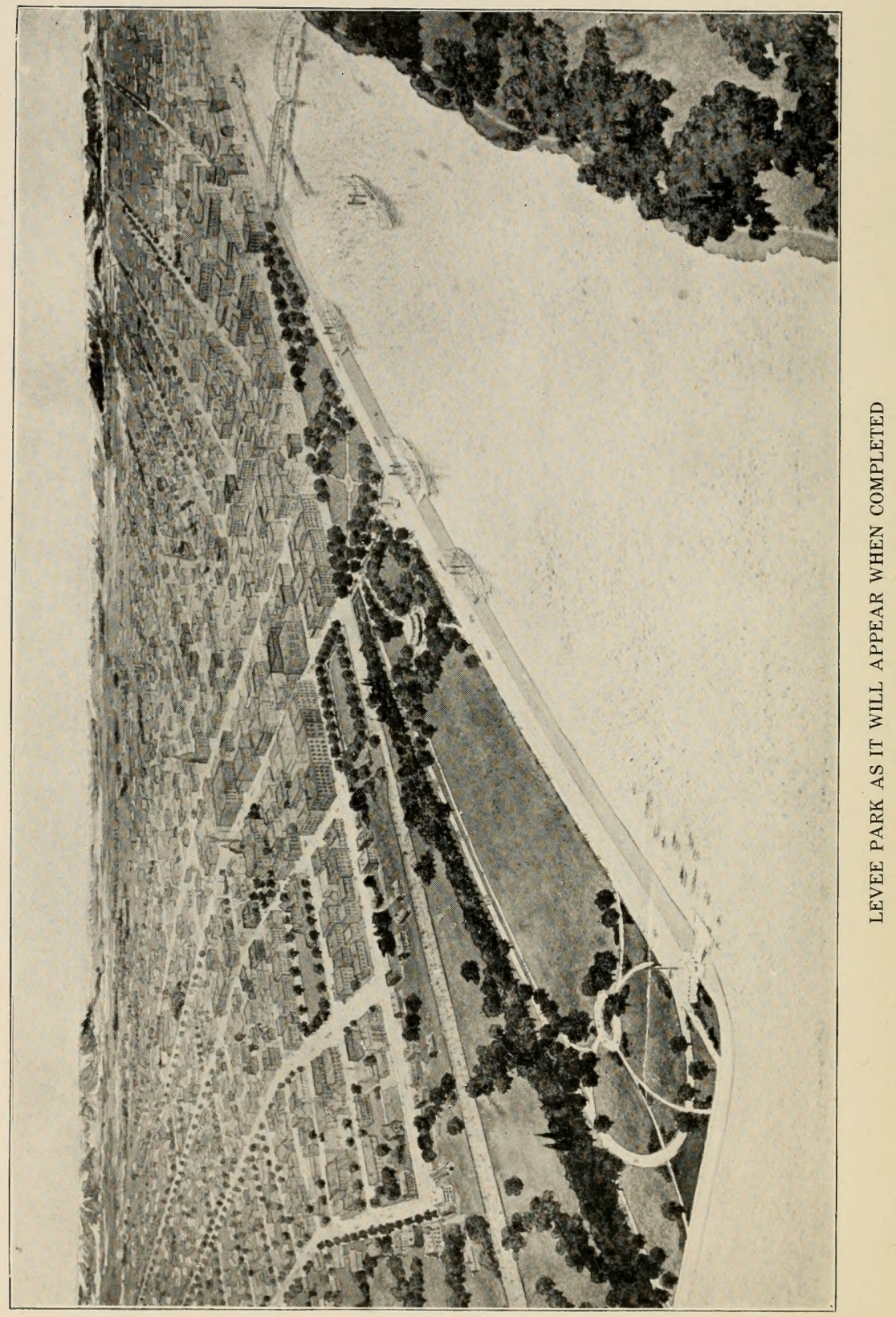




\title{
THE MAKING
}

\author{
of $a$ \\ Park System in La Crosse
}

\section{REPORT}

\author{
by \\ JOHN NOLEN, Landscape Architect \\ CAMBRIDGE, MASS.
}

1911

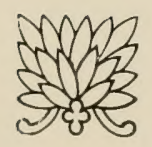

THE INLAND PRINTING COMPANY

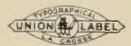

La Crosse, Wisconsin 


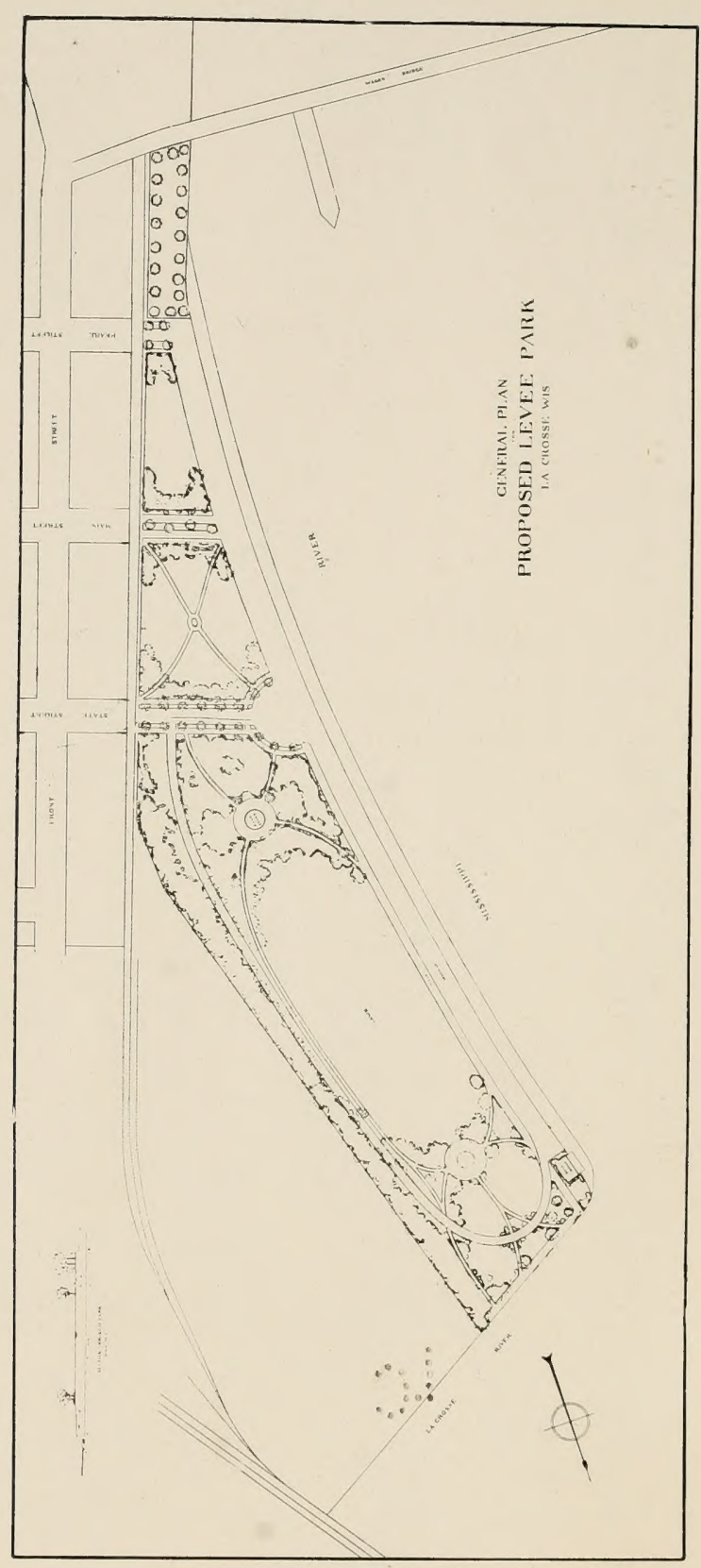

Clit: 


\section{Plark Commission}

Ia Crosse

::

$2 W_{\text {isconsin }}$

J. M. HIXON, Chairman

L. F. EASTON

E. L. COLMAN

HENRY GUND

FRED SCHNELL, Secretary

JOHN NOLEN, Landscape Architect

JOHN H. FORRER, Park Superintendent 


\section{flarks}

"The life history of humanity has proved nothing more clearly than that crowded populations, if they would live in health and happiness, must have space for air, for light, for exercise, for rest, and for the enjoyment of that peaceful beauty of nature which, because it is the opposite of the noisy ugliness of towns, is so wonderfully refreshing to the tired souls of towns-people." -Charles Eliot.

"In scarcely anything to be determined by local public opinion acting influentially upon local legislation and administration, is a city likely to be so much made or marred for all its future as in proceedings in prosecution of a park project.

"For every thousand dollars judiciously invested in a park the dividends to the second generation of the citizens possessing it will be much larger than to the first, the dividends to the third generation much larger than the second. * *

"That those in charge of a park work may proceed economically; they must be able to proceed with confidence, method, and system, steadily, step after step, to carry to completion a wellmatured design."-Frederick Law Olmstead. 


\section{Plans and Drawings}

1. Bird's Eye View of Levee Park.

2. General Plan for Levee Park.

3. General Plan for Copeland Park.

4. General Plan for West Avenue Playfield.

5. General Plan for Adams Street Playground.

6. General Plan for a City Park System for La Crosse. 


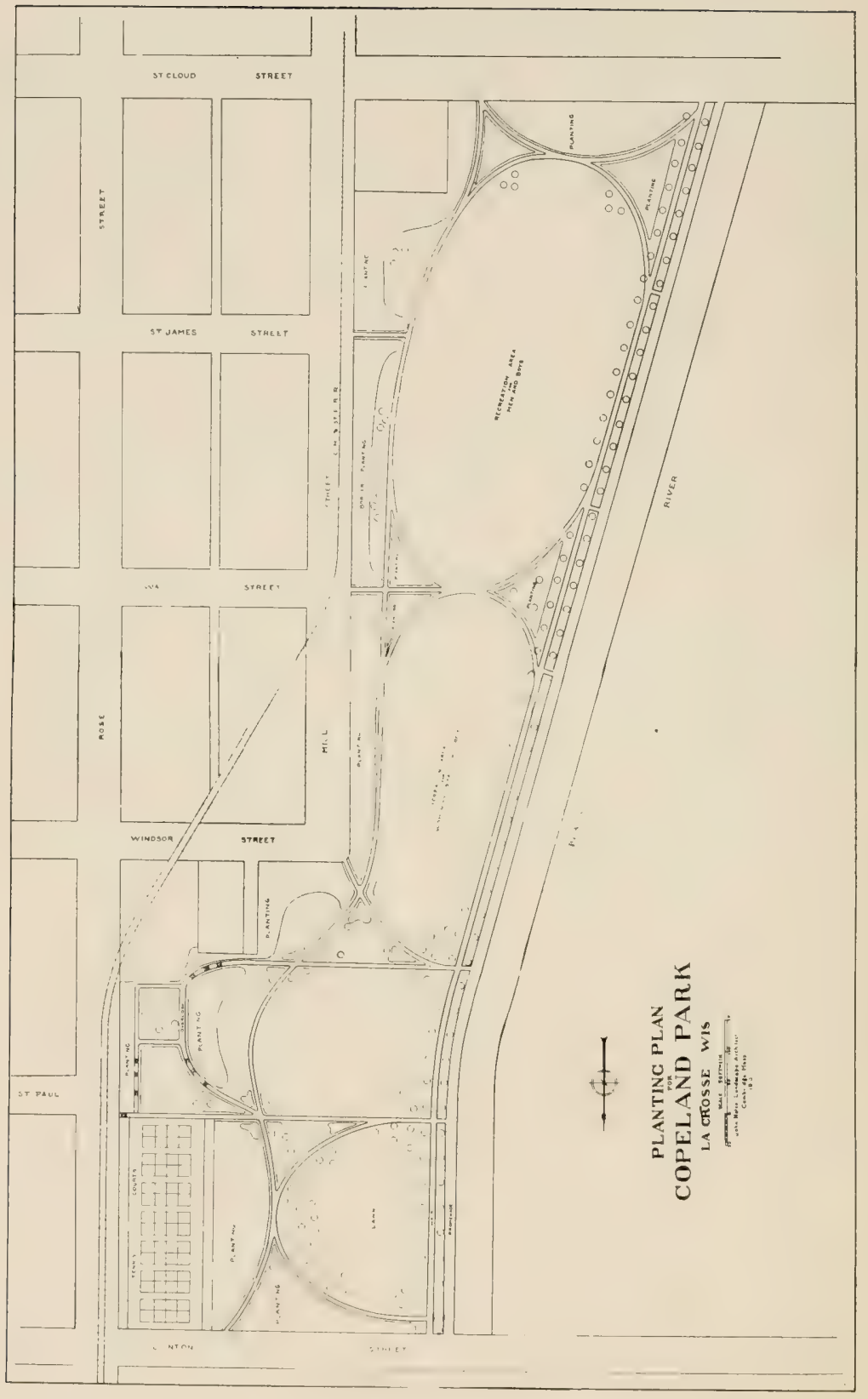




\section{THE MAKING OF A PARK SYSTEM IN LA CROSSE.}

No better illustration could be given of the making of a park system by a small city than the recent experience of La Crosse. It should be recalled that three years ago it had not even a park commission, and it is less than two years since the actual work of park construction was begun. Yet it has to-day the substantial framework of a comprehensive park system that is equalled by few cities, if any, of the same size. This achievement is so notable and the steps by which it has been brought about are so little known, even to many of the citizens of La Crosse, that I believe it worth while to review briefly the methods that have been used, to describe the general character of the parks and playgrounds themselves and to draw certain conclusions that seem justified by the first year's work of the La Crosse Park Commission.

\section{Pettibone Park Was the Beginning.}

The beginning of parks in La Crosse is to be found in Pettibone Park, a naturally beautiful Island in the Mississippi River, directly opposite the business section of the city, but unfortunately situated within the boundaries of the State of Minnesota. Established in 1890 as a public pleasure ground, through the generosity of $\mathrm{Mr}$. A. W. Pettibone, this Island Park at first supplied the demand for public parks and then created an insistent demand for more. Never a city park in a complete sense, it has, nevertheless, always been open to the free use of the people. Its administration is vested in a special park board,* appointed by Mr. Pettibone and the funds for the acquisition of the land, for construction and for maintenance have been provided by the same generous and publicspirited individual. He has placed in the hands of the aforesaid Park Board the sum of $\$ 50,000$, the income from which is to be used in the proper maintenance of the park. Pettibone Park

*The present members are: J. M. Hixon, President; F. P. Hixon, VicePresident; Geo. H. Gordon, Sec'y.; G. W. Burton, Treasurer; E. L. Colman; Mayor John Dengler. 

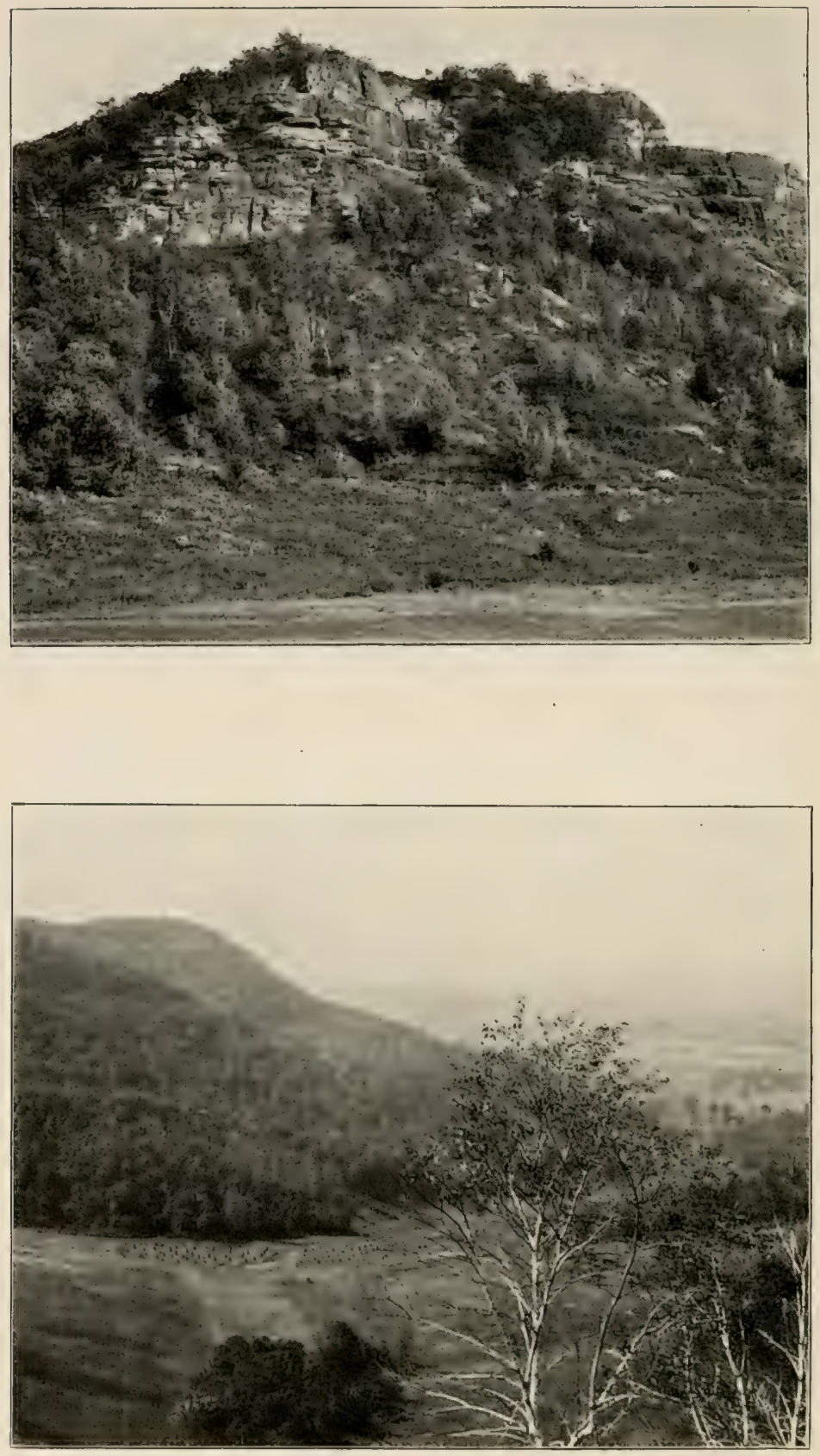

GRANDAD BLUFF AND PROPOSED COULEE PARK 
contains about two hundred acres. It has an exceedingly irregular shore line, picturesque and beautiful lagoons; and if properly developed might easily rival the famous Belle Isle Park of Detroit. Indeed, the views of River scenery are much finer than those from Belle Isle. But to make Pettibone Park a thoroughly satisfactory recreation ground, it should be raised securely above the high water of the Mississippi River and the control and jurisdiction of the Island transferred by the Legislature of Minnesota to the City of La Crosse.

Yet, after all, Pettibone Park only prepared the way. The real beginning was made when the Common Council of La Crosse on May 15, 1908, passed the ordinance creating two park districts and establishing a Board of Park Commissioners. By this ordinance a non-political, unpaid commission of four members was provided for. These Commissioners were to be appointed by the Mayor, subject to the approval of the Common Council. Acting in accordance with this ordinance, Mayor Wendell A. Anderson, whose splendid services for parks and the welfare of the city generally, cannot be overestimated, appointed as the first Board of Park Commissioners, J. M. Hixon, L. F. Easton, E. L. Colman, and Henry Gund,-all men of public spirit, high standing and great ability.

\section{Landscape Architect Engaged.}

The next step was the selection by the Board of a landscape architect as its expert adviser and the arrangement soon after for a public mass meeting to present to the general public the tentative plans for a park system and the reasons for such a system in a city like La Crosse. The meeting was held in the Opera House. The arrangements were unusually well made, the local newspapers co-operating heartily and as a result a large and representative audience completely filled the Hall. The Mayor presided. The speakers pointed out that in nothing is the welfare of a city so permanently influenced as in the selection of sites for parks and the construction of an adequate system of play and pleasure grounds. A park system, it was said, should be comprehensive, including city squares, equipped and supervised playgrounds, small and large parks and scenic reservations, all connected, one with another, by parkways or boulevards. And to be adequate, such a system should not only meet the demands of all classes of the people in all parts of the city to-day, but should reasonably anticipate the needs of the future. The contribution that parks make to pleasure, to health 

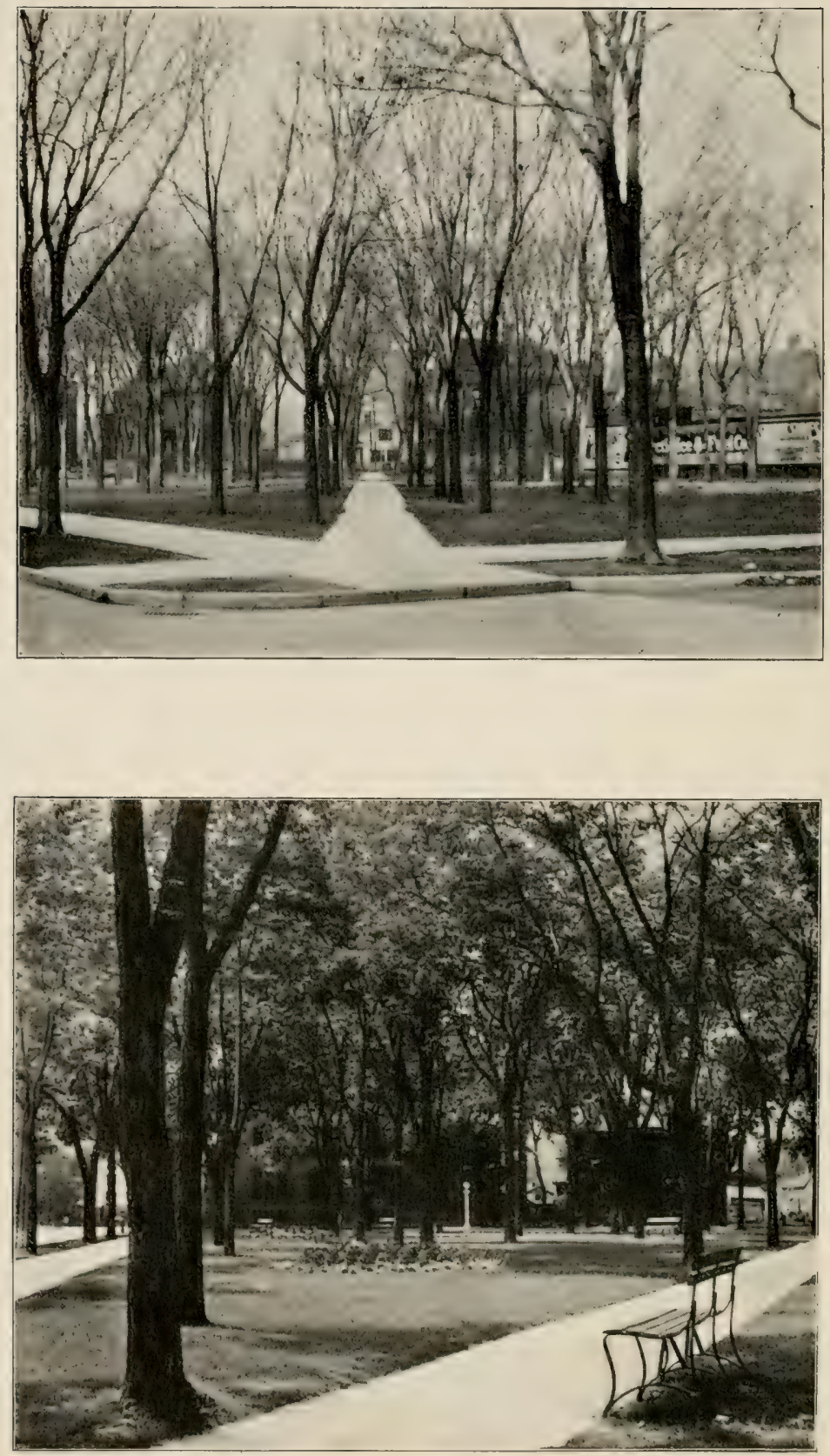

MAIN STREET SQUARE BEFORE AND AFTER IMPROVEMENT 
and, both directly and indirectly, to the prosperity of cities was illustrated by the experience of other places. The four conclusions to which the addresses of the evening pointed definitely were: (1) That Park lands for the City of La Crosse would never again be so cheap; (2) That once acquired, they would steadily increase in value; (3) That the experience of every city that has judiciously undertaken park improvements had demonstrated that they pay for themselves *; (4) That the adoption of a permanent park policy is more than likely to bring rich gifts of land and money for park purposes. Of the general soundness of these views, the audience was convinced, and at the conclusion of the meeting, the following resolutions were unanimously adopted:

\section{Massmeeting Adopts Resolutions.}

"Whereas, The City of La Crosse is in need of greater park privileges and facilities and is admirably adapted by situation and natural advantages for the carrying out of a general plan for the establishment of a comprehensive park system,

"Now Therefore, Be it resolved by the citizens of La Crosse in mass meeting assembled this 18th day of November, 1908, that we are in favor of the adoption and execution of a plan of park improvement which will tend to beautify our city and minister to the comfort and pleasure of all our citizens. And be it further

"Resolved, That we indorse the steps already taken in this direction by the appointment of a park commission and heartily approve the proposed action of the Common Councill in levying a one mill tax to be set apart and expended under the direction of the park commission for park purposes, and pledge our support to all future efforts and actions of the commission and common council for the accomplishment of these purposes. And be it further

"Resolved, that our thanks be and are hereby extended to Mr. John Nolen for his able, interesting and instructive lecture and to the park commission for its efforts in providing for this opportunity to hear the same. And be it further

"Resolved, That these resolutions be transmitted to the common council of the city of La Crosse and a copy thereof to the

*The conclusion of a citizens' committee appointed by the Madison City Council, was that from 10 to 15 per cent of the increase of real estate values within that city since 1893 was due to the park and drive work. This would mean an annual income to the City from taxes of more than twenty thousand dollars. See "Madison Parks as a Municipal Investment." 


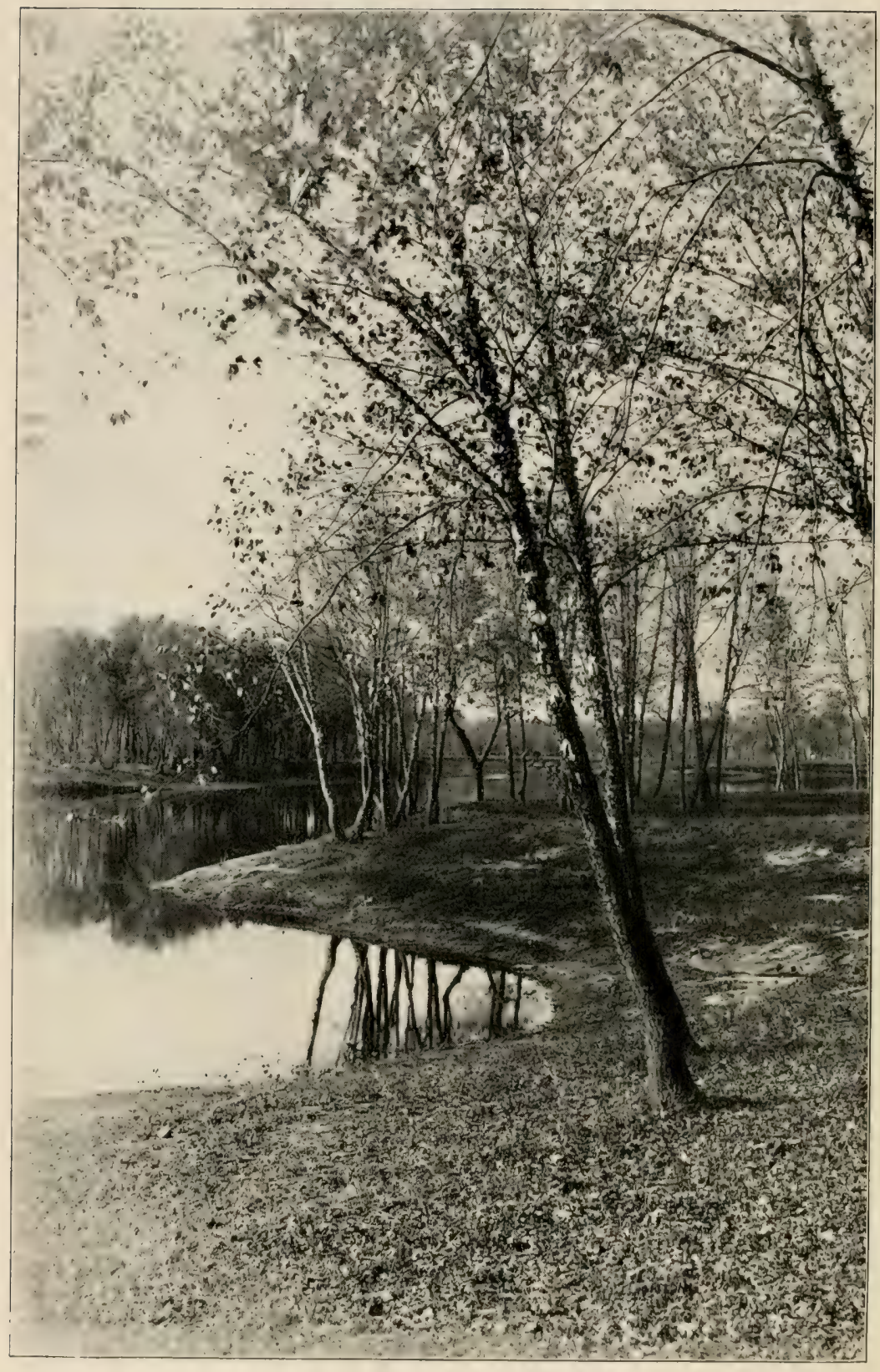

PETTIBONE PARK LAGOON 
park commission and to the daily and weekly newspapers published in the city. And be it further

"Resolved, That we are in favor of issuing bonds in such amounts as may be necessary to carry out the recommendations of the park commission."

\section{Tax Levied for Park Purposes.}

At a meeting of the Council held a few days later, this enthusiastic action of the people was confirmed by the levying of a one mill tax for parks and later by the issuing of bonds for seventyfive thousand dollars for the purchase of land and for the necessary construction. Thus in six months the work of park making in La Crosse was successfully inaugurated.

It requires but a brief residence in La Crosse to see that the methods of procedure followed in beginning the park work were not different from the methods which the city had already followed in other matters. In paving its business and residence streets with an unusual degree of excellence, in placing all telegraph and telephone wires underground a decade ago, in hospitality to strangers and in other practical and progressive ways advancing the civic life, La Crosse had already established an enviable reputation. Thus the park project followed approved and successful precedents and was not looked upon in any sense as an experiment.

\section{Sites Naturally Fitted for Parks.}

It was the aim of the Park Commission and its landscape adviser to select property that was naturally fitted for park use, that could be developed economically, that would reflect and preserve the characteristic and beautiful topographical features of La Crosse, and that, when improved, would constitute a whole, each part having relation to every other part, and together forming a comprehensive, well-distributed system in which the needs of each section were adequately and fairly provided for. The situation of the City is remarkable and of great beauty. With one of the finest parts of the Mississippi River on the west and a noble range of high and rugged bluffs on the east, it occupies a broad and fertile valley, offering an ideal site for both business and residence purposes*. The most striking and characteristic natural features are, of course, the river and the bluffs. It was decided at once that

*The valley extending from $\mathrm{La}$ Crosse to Salem, Bangor, Rockland, Sparta and beyond is a marvel of loveliness. 

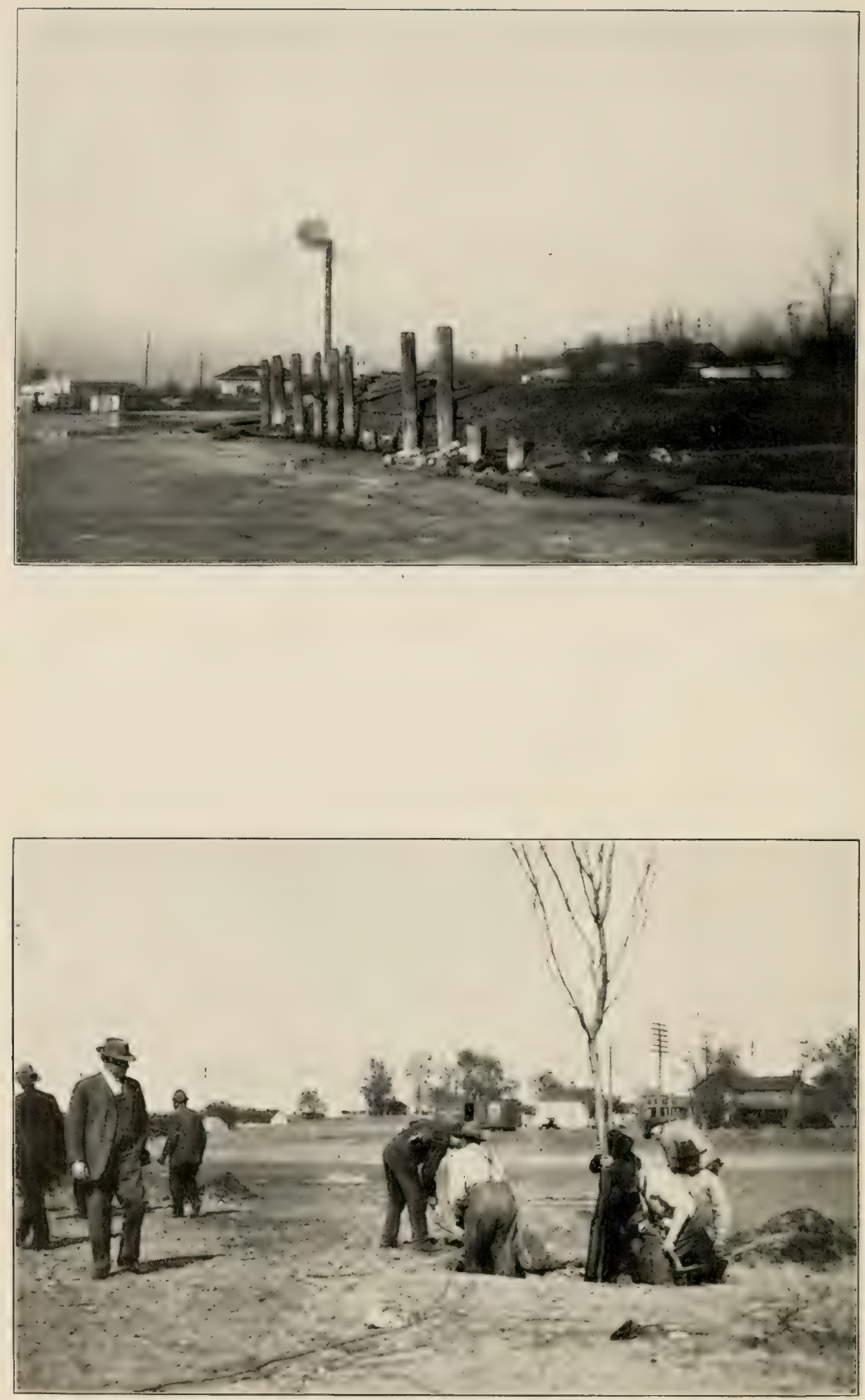

COPELAND PARK BEFORE 

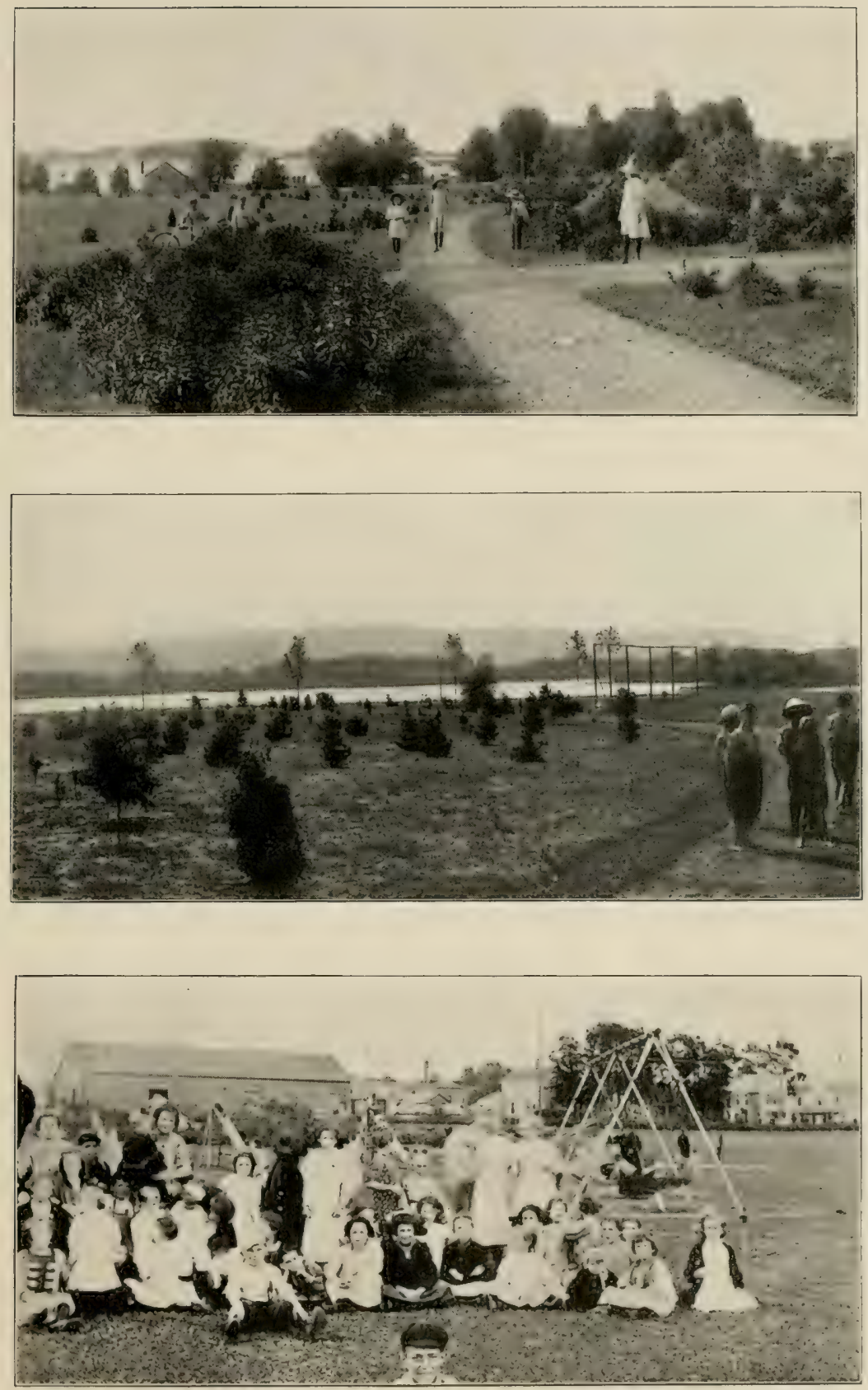

COPELAND PARK AFTER 

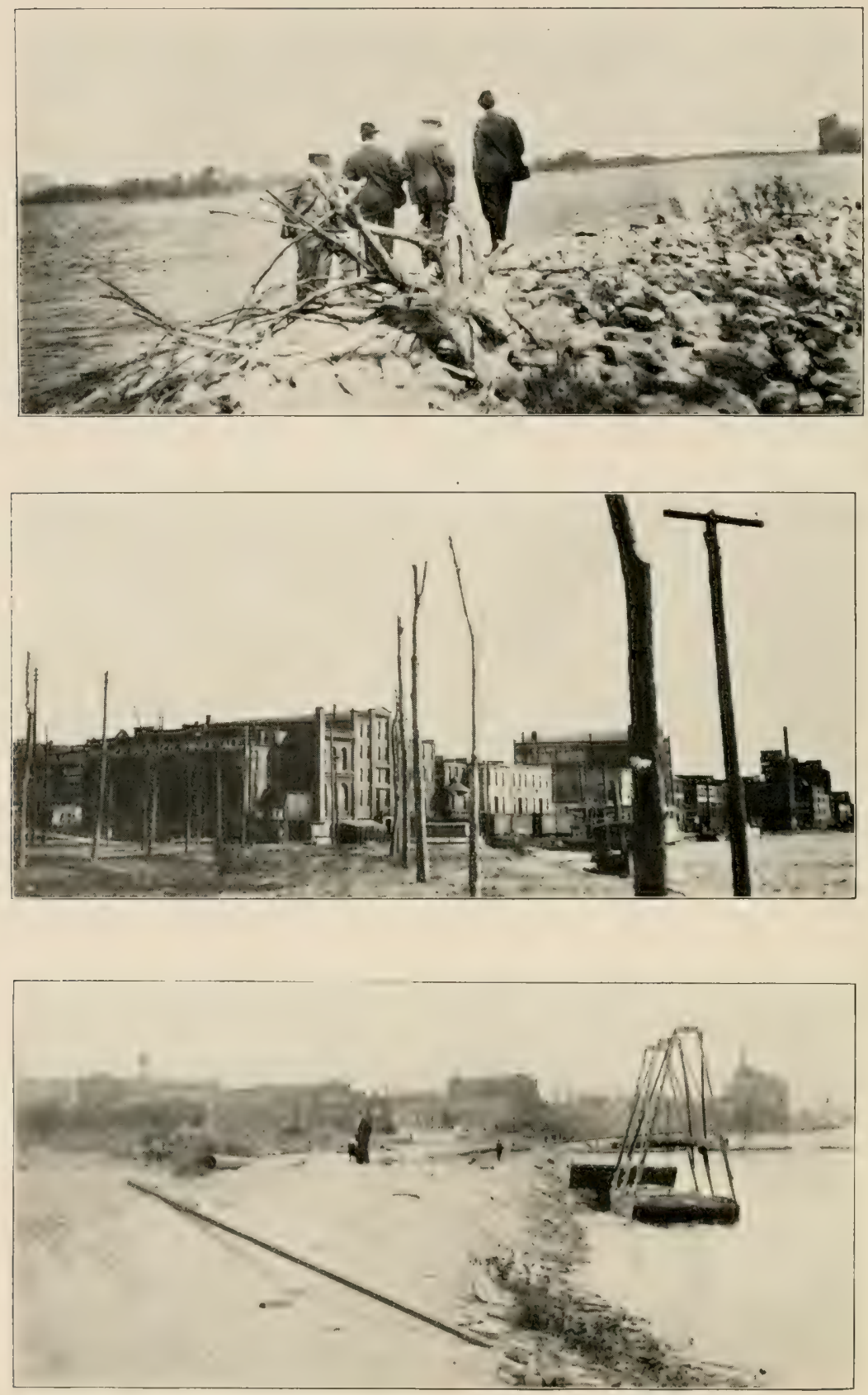

LEVEE PARK BEFORE 
these should be included in the park plans and that all the forms of recreation that river and bluffs make possible should be provided.

The existing parks available as a nucleus for the new system were the two half blocks in the built-up section of the city, Myrick Park and Drive and the Losey Boulevard. After a great deal of investigation on the ground, supplemented by careful study and plan making, the following system of parks, parkways, squares and playgrounds was adopted:

\section{Park System for City of La Crosse.}

(1) Copeland Park. This is a tract of more than twenty acres in North La Crosse with a frontage of half a mile on the Black River, commanding some of the finest views of the Minnesota bluffs. A wide promenade runs all along the water front and the plan for the park includes provision for many forms of active recreation and quieter relaxation. Its arrangement is in keeping with the best modern thought and practice, which show a tendency to make much greater use of our parks than heretofore. They are looked upon less and less as luxuries, as beautiful pictures merely for occasional holiday enjoyment; they have become an essential part of every day life in cities. While the making of Copeland Park called for extensive filling by dredging from the River, the cost of the property was relatively low and a very considerable area was presented as a gift to the City by Mr. F. A. Copeland, in recognition of whose generosity and fine citizenship, the Park received its name.

(2) Levee Park. This will contain about twelve acres and is happily situated at the natural water approach to the City and close to the business center. The plan for this Park is more ornamental than Copeland Park. The water front will continue to be used for business purposes, but the undeveloped area between the River and the railroad tracks will be filled, improved and made available for recreation.

\section{Largest and Most Beautiful Park.}

(3) Grandad Bluff and Viller's Coulee. The Park which it is proposed to create at this point will be the largest and most beautiful in La Crosse. In fact, few cities have such an opportunity. Grandad Bluff is the highest in the neighborhood of La Crosse and rises majestically to a height of 1,172 feet. The Coulee which nestles in its side affords a type of scenery of great attractiveness. It is beautiful and restful, as well as adapted for a pleasure ground 

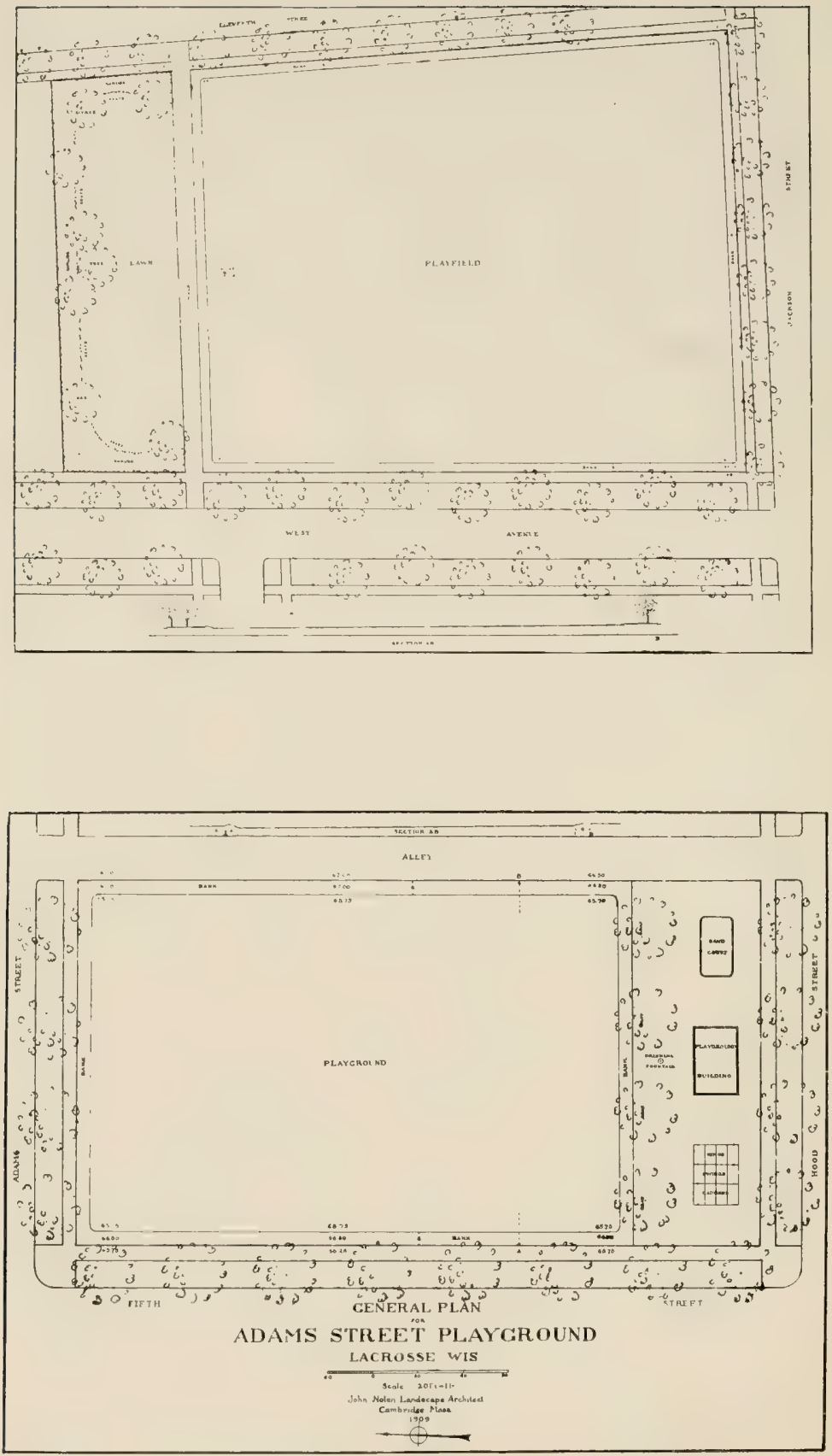

WEST AVENUE AND ADAMS STREET PLAYFIELDS 
for city people as any that can be conceived. This property is only partially aequired but when completed, it will probably include over four hundred acres. It is as good an illustration of ready-made park as could be found, and except for road making, the cost of its improvement will be slight.

(4) West Avenue Playfield. The acquisition of this three acre field at West Avenue and Jackson Street - more than a full city block in extent-illustrates the interest of the Park Commission in Playgrounds for the children. The entire area has been carefully graded, improved, and planted, providing for all-the-yearround use, including field games and skating, and a small park-like area for the recreation of the children's parents.

(5) Adams Street Playground. Although smaller in area, this property corresponds in character and development to the West Avenue Playfield. It provides for its neighborhood a good base-ball field and a place for skating in winter. The south end of the lot is to be furnished with sand gardens, swings, ladders, etc., for the smaller children. There is also room for a Playground Shelter Building which has been constructed in such a way as to permit of its use by the City as a voting booth.

(6) Block at George and Livingstone Streets on the North side. It is proposed to acquire and improve this block much after the manner of the Adams Street Playground.

(7) La Plume Island. At present this Island is low and requires filling. When filled and improved, it will make for the South End of the City a park much like Pettibone Park.

(8) Forty acres at the South End of West Avenue. This property is not imperatively needed by the City for immediate use, but it is a valuable reservation for the future and illustrates the foresight of the Park Commission and its efforts to anticipate at least the most important needs of the period immediately ahead, for the City is growing rapidly toward the south.

\section{Plan to Double Size of Main Street Square.}

(9) Main Street Square. The City already owns one-half this Square. By purchasing the other half, which can still be had on reasonable terms, a splendid open space would be secured in the heart of the City, around which public and semi-public buildings could be placed. The Public Library, one of the public school buildings, the new Y. MI. C. A., the Masonic Temple, and the Congregational Church now front on the half block. By extending it as proposed, the setting of all these buildings would be greatly 

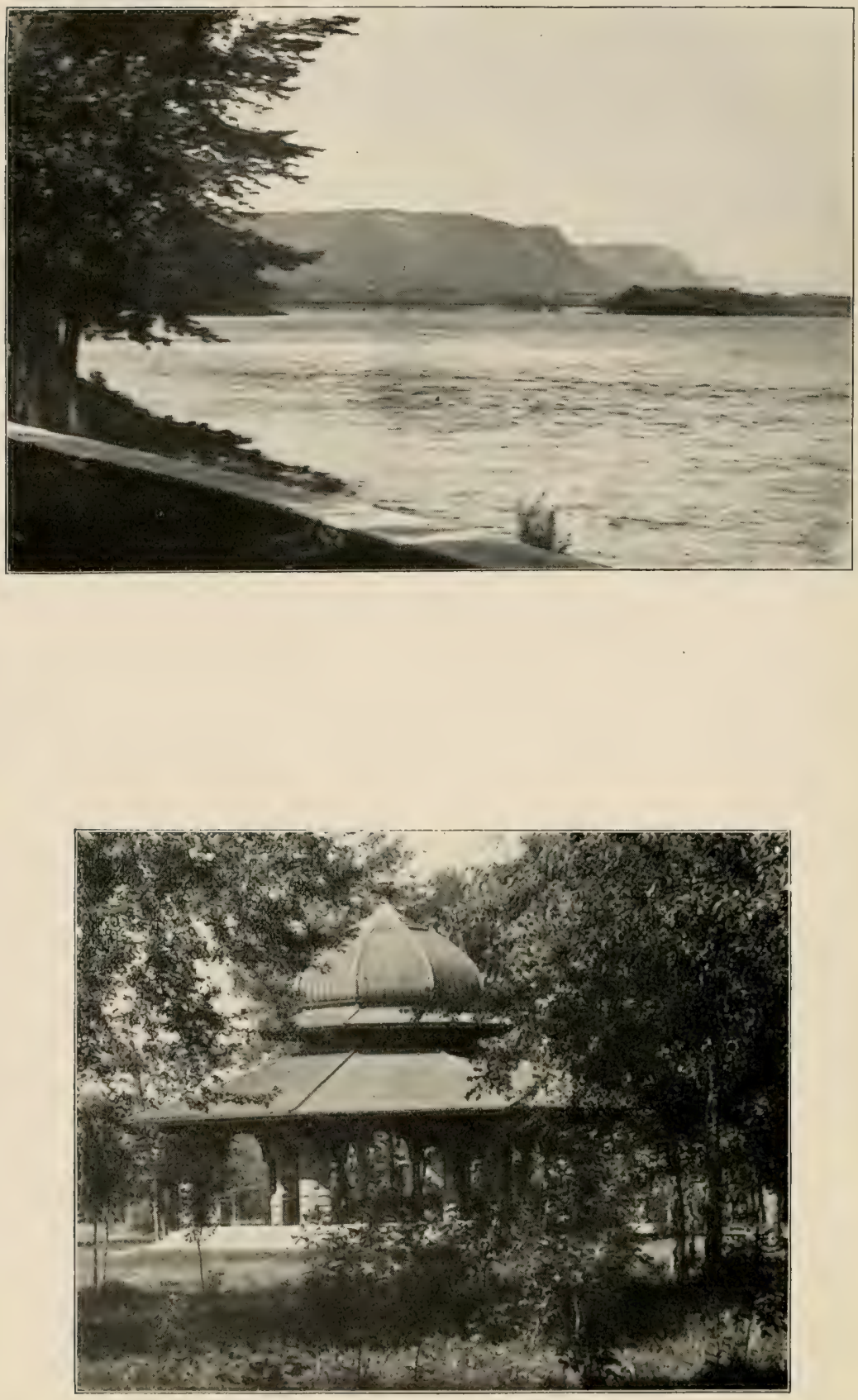

VIEWS OF PETTIBONE PARK

COPYRIGHT BY GEO. E MARINER 
improved and beautiful and appropriate sites would be obtained for as many more. There is no other property in the central part of the City which offers so good an opportunity and it should not be lost by delay.

(10) Reservation on the Viaduct between North and South La Crosse. Such a property is now easily secured and would provide a park for the future at. a central situation.

(11) Inter-State Fair Grounds. This tract of 37 acres is now owned by the City and it is proposed later to make it the principal athletic ground for the older boys and young men of the City. Here there is room for a very complete provision for all the field sports, tennis, etc. The location is admirable for the purpose.

\section{System of Parkways and Boulevards.}

(12) Parkways. It is proposed to connect all these parks, squares and praygrounds by a complete system of parkways and boulevards. Beginning, say, at the Levee Park, it would go out State to Seventh, north on Seventh across the Viaduct to Rose, to St. James, to Avon, to Clinton, to Kane, to Livingstone, to George, and to the City limits. Later the roads indicated on the general plan to the north, east, and south of the City would be improved so as to make a continuous circuit, bringing the traveller back to Seventh Street on the South Side, on to State Street, and to the Levee Park where the start was made. This circuit of fifteen miles might not be entirely free from some relatively commonplace sections, yet most of it could easily be made very attractive. Even now a very large percentage affords views both near and far that could not be equalled by the best parkways in the larger cities. In addition to this Cireuit, West Avenue, running north and south, and Cass street, east and west, should receive the attention due to specially important thoroughfares.

This brief description is intended simply to draw attention to the main elements of the La Crosse Park System. Incidentally there followed also an improvement and extension of school grounds in which the Park Commission assisted. The general plan of the City, and the plans of the Parks and Playgrounds that accompany this report supplement the outline here given. Copeland Park, the West Avenue Playfield, and the Adams Street Playground are already completed and in use. The co-operation of the railroads has been a factor of importance. 


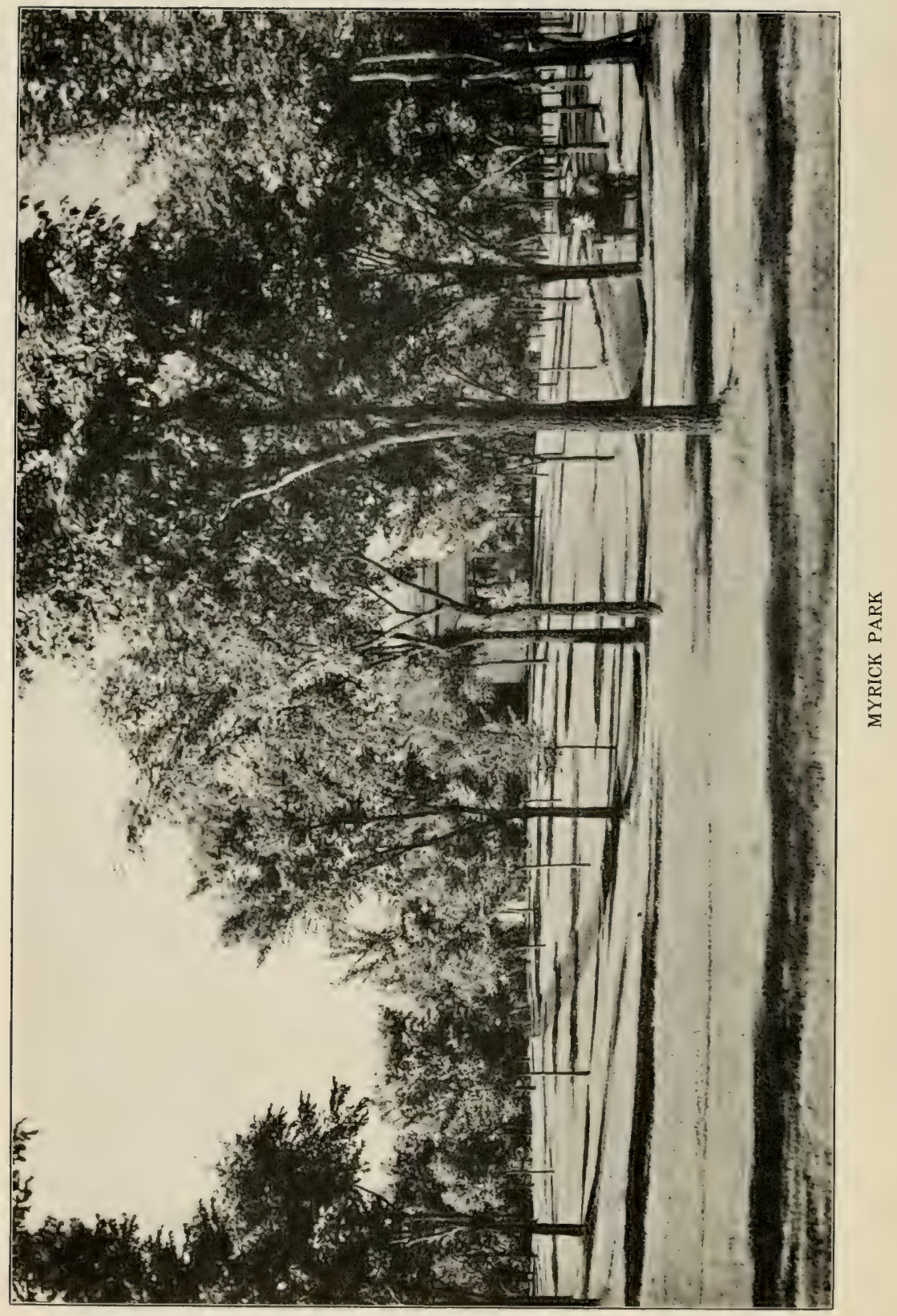




\section{Successful Methods Followed.}

The methods followed at La Crosse, a city of but 31,000 population, it should be remembered, have been so successful and the results so satisfactory that it is worth while to note the lessons which the experience gives as a guide for the future not only of La Crosse but of the many other small eities in the United States which are now in a position not unlike that which confronted La Crosse two years ago.

The six points of most significance are:

(1) The main reliance from the beginning was upon public action and public support. The people were taken in on the ground floor, so to speak, and made to feel that the work was not only to be for them, but was to be done by them. The Parks and Playgrounds were put in exactly the same class as the public school and the public library and in renewing the appropriation this year, the members of the City Council showed that they looked upon them in this way. In the case of La Crosse, and it should be the case elsewhere, generous public action has been supported and supplemented by generous private action, the private gifts to the La Crosse Parks probably equalling the annual appropriations by the City.

(2) The Park Commission has, from the start, applied the efficient methods of private business to the administration of this new city department and with similar good results. Each City dollar was expected to bring a full dollar's worth of work or material -and it did.

(3) Before a step was taken toward execution, a complete general plan was prepared for all the parks and playgrounds included in the present system. This inspired public confidence in every part of the City. Too much emphasis cannot be given to beginning in this way. It not only wins confidence; it prevents mistakes and contributes to economy in many directions.

\section{Cost for Park System only Fifty Cents Per Capita.}

(4) The cost of these parks and playgrounds for La Crosse has not been heavy. The Council has issued twenty-year bonds for seventy-five thousand dollars and the one mill tax has yielded a little over twenty thousand dollars a year for two years. Against the bond issue, the City has an asset which will steadily increase in value and always be worth more than its cost. It is to be regretted that the law of Wisconsin limits all bond issues to twenty years. In the case of land purchase, it would seem that the law 


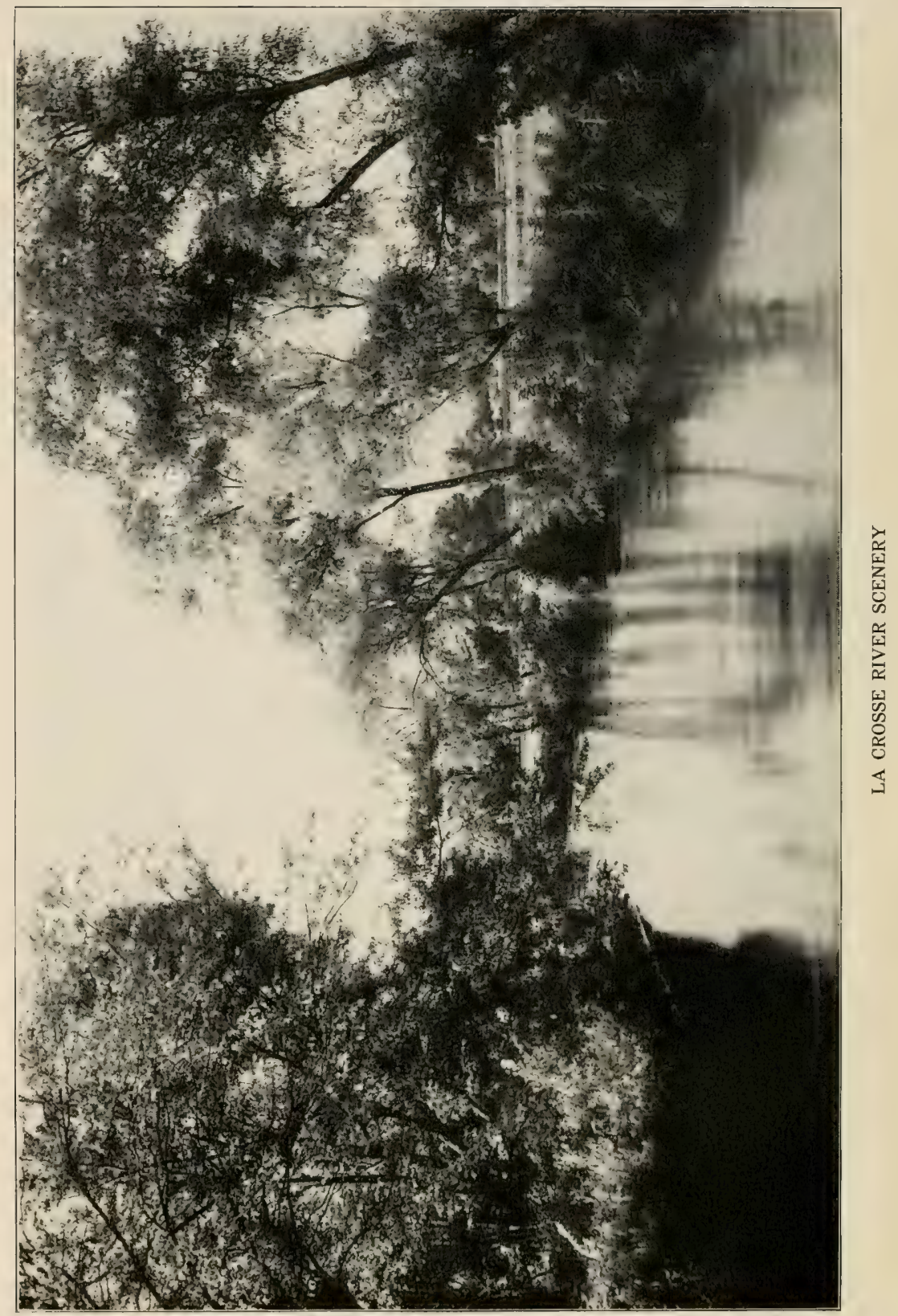


of Minnesota, which permits such issues to be for forty or fifty years, would be better for future as well as present generations, because it would lead to a more adequate and more economical provision for the future. But even under the present law and the extra expenses inevitable during a period of heavy construction the annual cost has not exceeded fifty cents per capita.

(5) Another conclusion justified by the experience of La Crosse, is the possibility, especially in the smaller places, of enlisting in the service of the community the most honorable and able men. If an unpaid Commission is created, free from political influence, under conditions that permit of a large public service, it will always be possible, as at La Crosse, to find qualified men to accept. These men have had a hand in a piece of constructive public work in which they can always take pride and they have won the gratitude of the people of their own city.

(6) The final lesson of the La Crosse Parks is their effect upon the civic spirit of the entire community. There has been a noticeable quickening of civic pride and an awakening of interest in civic affairs which is worth all that these public improvements have cost in money and personal work.

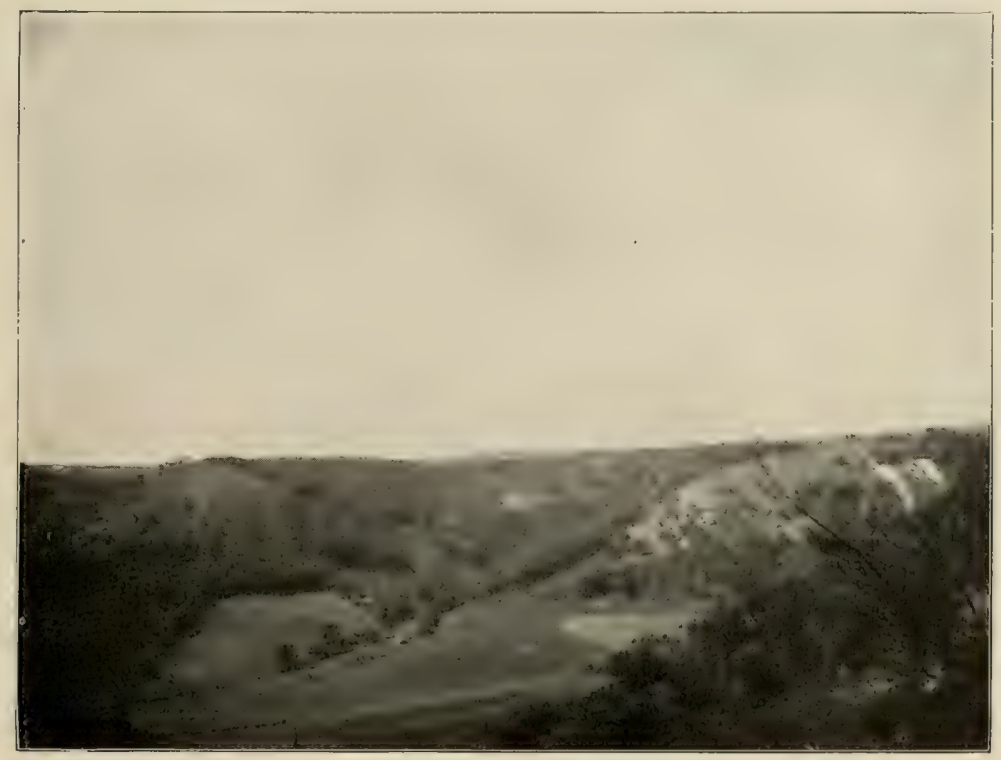

VIEW OF PROPOSED COULEE PARK

Twenty-Nine 


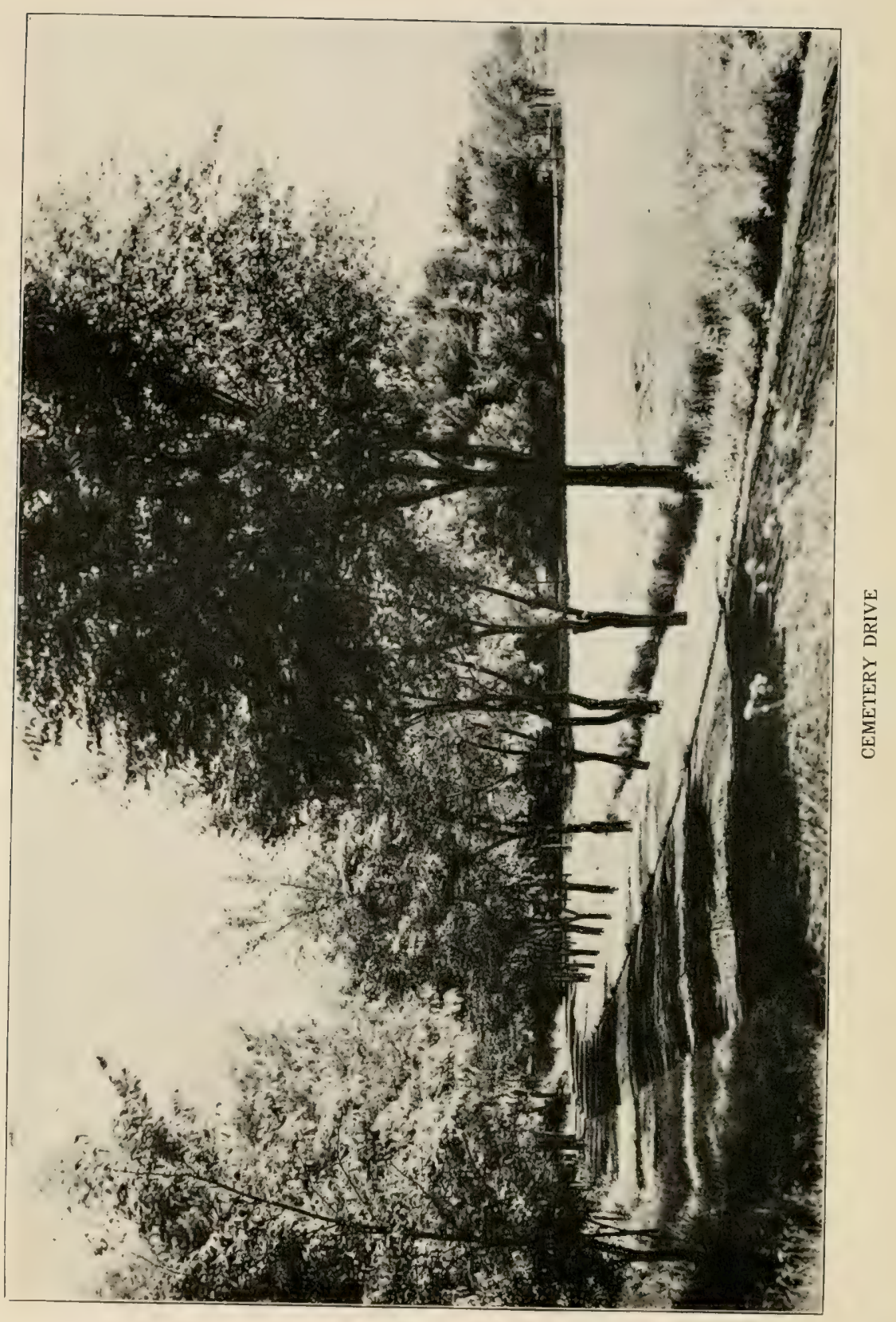




\section{An Acknowledgment}

It seems proper and fitting that there should accompany this report of Mr. Nolen's which will become a part of the written history of La Crosse, a record of the names of the loyal and generous citizens who have by gift assisted in the work of park building. May their personal satisfaction equal the pleasure their generosity will give to the thousands in years to come: The following gave their river front property which made Levee Park possible:
J. J. HOGAN AND FAMILY
G. A. KAEPPLER
S. B. OATMAN
S. Y. HYDE
W. W. CARGILL FAMILY EMIL T. MUELLER
T. H. SPENCE ISIDORE SCHILLING

The following gentlemen subscribed the sum of forty-three thousand dollars to aid in the expense of making Levee Park:
HENRY GUND
L. C. COLMAN
H. L. COLMAN
E. L. COLMAN

F. P. HIXON

GEO. C. HIXON

L. F. EASTON

To aid in making a park on the North Side Mr. F. A. Copeland gave eight acres of land.

A piece of land adjoining Myrick Park and necessary for continuing the drive and completing the shore line was given by L. F. Easton.

Isle La Plume was given by the John Paul Lumber Company and the C. L. Colman Lumber Company.

\section{GRANDAD BLUFF PROPERTY}

This property was acquired by Ellen J. Hixon who was encouraged thereto by the interest taken and the subscriptions of the following persons:

DR. EDW. EVANS

ELSIE GILE SCOTT

GEO. ZEISLER

EUGENE PERKINS

H. J. HIRSHHEIMER

J. B. FUNKE

R. E. OSBORNE

HENRY GUND

F. A. COPELAND

G. HEILEMAN BREWING CO.
B. E. EDWARDS

E. E. BENTLEY

MRS. G. VAN STEENWYK

PAUL BROTHERS

GEO. H. GORDON

FORREST J. SMITH

COLMAN BROTHERS

L. F. EASTON

SMITH MFG. CO.

ELLIOT \& LOEFFLER CO.

LA CROSSE WATER POWER CO.

Respectfully,

J. M. HIXON,

President Park Commission. 



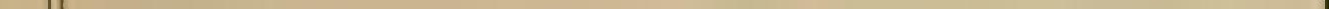





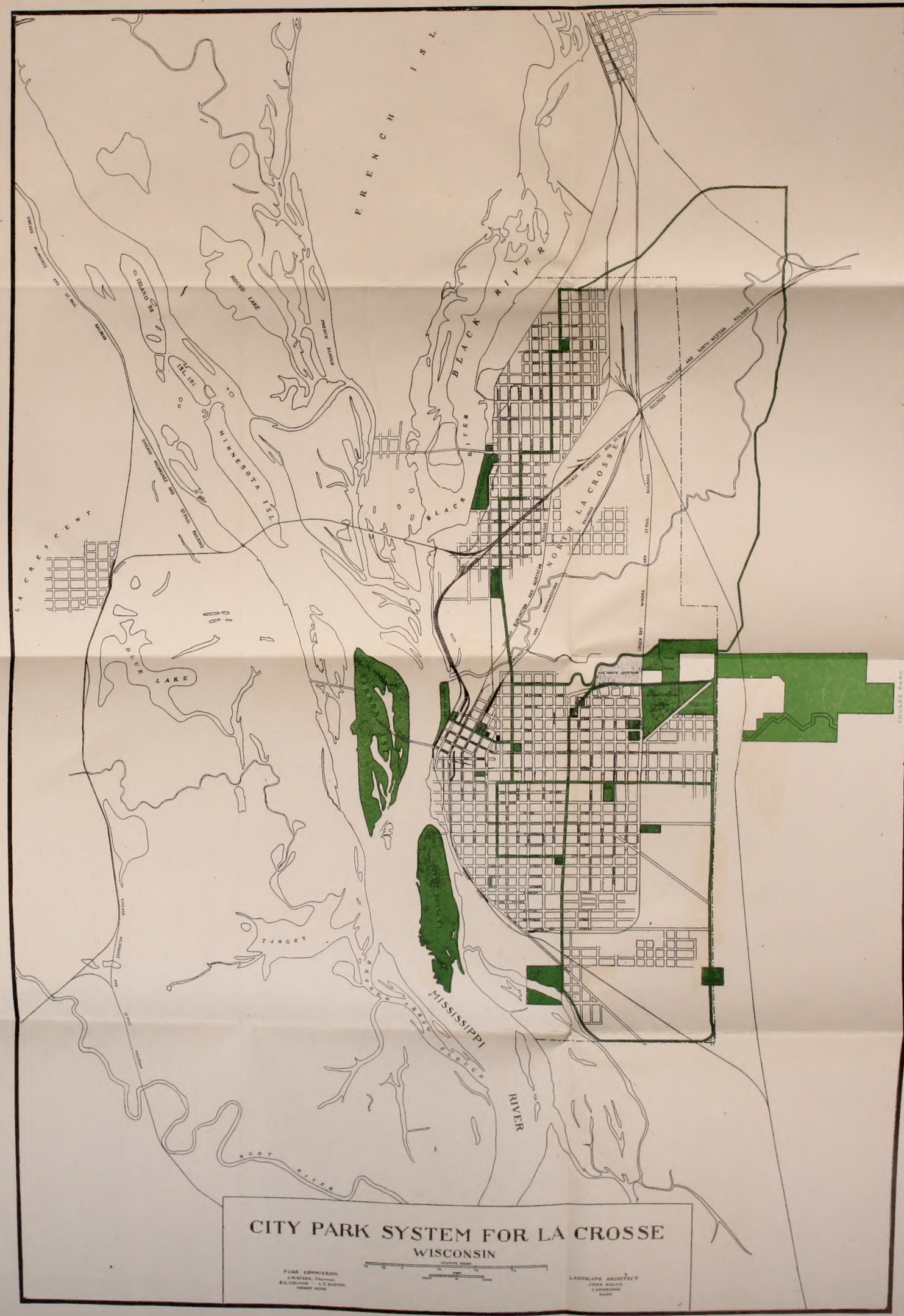


SEP 23 1911 
LIBRARY OF CONGRESS

|||||||||||||||||||||||||||||||||||||||||||||||| 